\title{
Modelling Water Related Ecosystem Services in a Heavily Modified Mediterranean Reservoir Using the Soil and Water Assessment Tool (SWAT) ${ }^{\dagger}$
}

\author{
Dionissis Latinopoulos, Alexandros Dimitriou and Ifigenia Kagalou * \\ Department of Civil Engineering, Democritus University of Thrace, 67100 Xanthi, Greece; \\ dlatinop@civil.duth.gr (D.L.); alexandros.m.dimitriou@gmail.com (A.D.) \\ * Correspondence: ikagkalo@civil.duth.gr; Tel.: +30-2541-079-601 \\ + Presented at the 4th EWaS International Conference: Valuing the Water, Carbon, Ecological Footprints of \\ Human Activities, Online, 24-27 June 2020.
}

Published: 7 August 2020

\begin{abstract}
Lake Karla (Thessaly, Greece) drainage and morphological alterations affected all waterrelated ecosystem services (ES). The lake is restored as a multipurpose reservoir, whose inflows are boosted with pumping from Pinios River. The Soil and Water Assessment Tool (SWAT) simulated the watershed's hydrology and the reservoir's function, under a climate change scenario to assess water related ES. Official timeseries were used for five different scenarios with simulation period until 2100. The results suggest that the reservoir's water quality is impacted by summer irrigation and by the water volume from the Pinios during winter. As for the selected ES, in almost all scenarios, they seem negatively affected.
\end{abstract}

Keywords: SWAT; irrigation; climate change; ecosystem services; Karla reservoir

\section{Introduction}

The ecosystem services (ES) concept is becoming more and more acknowledged in science and decision making, resulting in several applications in different case studies for environmental management, but it is still developing in terms of definitions, typologies and understanding of its complexity [1]. ES meet the criteria of being adequate human-environmental system indicators as they are policy-relevant representations of the system's state [1] and they embrace the ecological, biophysical and socio-economic aspects necessary to evaluate the sustainability of human-coupled ecosystems [2]. European policy has placed increased interest in the concept of ES, and they are embedded in European Union (EU) Environmental Policies as the Biodiversity Strategy, the Marine Strategy Framework Directive [3,4]. Moreover, many development goals are likely underpinned by the delivery of one or more ES and water related ones affect the majority of United Nations Sustainable Development Goals [5]. Especially for management, research focuses on simulating and conserving hydrological provision ES for various land uses, climates and human activities [6].

Especially in Mediterranean basins, sustainable water management is crucial not only for negating the multiple pressor effects that the waterbodies are subject to, but also for ensuring the multiple related ES (potable, industrial and agricultural water provisioning, food processing and ecosystem preservation). Multiple pressures, especially under climate change, have a particularly strong effect on the catchments of lakes and reservoirs while non-impacted lakes are scarce in Europe [7]. A total of $48 \%$ of wetlands in the Mediterranean basin have disappeared since 1970, according to a recent analysis [8] $-15 \%$ higher than the global average. The Mediterranean region has proven to be extremely sensitive also to the effects of climate change. The Intergovernmental Panel on Climate Change [9] has identified the Mediterranean region as a climate change hot spot. In the eastern 
Mediterranean, especially, most countries are already experiencing a rise in temperature and an increase in water scarcity, forest fires, drought frequency and desertification growing rates [10].

Mathematical simulation models can be useful tools for the effective water management as they can predict complicated the bio-geo-hydro-chemical mechanisms. The Soil and Water Assessment Tool (SWAT) has been proposed as a means to help quantify ES in watersheds [11]. It is a prominent process-based model, which has been widely used for agricultural management simulation (e.g., $[12,13])$, while it has also been applied for simulating agricultural pressures on biological quality elements [14] and further for the evaluation of management actions towards the implementation of Water Framework Directive (WFD) [15]. Reviewing the past literature, many studies have focused on provisioning ES as the water yield, crop production, food processing [16], by regulating ES as sedimentation, water quality, nutrient loading, and groundwater flow [11,17].

The re-established Lake Karla, located in Eastern Thessaly (Greece), was drained in 1962 to protect the surrounding farmlands from flooding and to increase agricultural area. Environmental, social and economic problems that resulted from the wetland loss led to the reconstruction of the lake, aiming to provide irrigation water and flood protection to the Karla basin as well as to restore part of the wetland's environmental functions. Due to its importance in hydrological, biodiversity and ES terms, the re-constructed lake has been intensively monitored the last years (e.g., $[18,19])$. The reconstructed lake occupies the lowest part of the former lake [20]. The lake covers an area of $38 \mathrm{~km}^{2}$ and contains a water volume between 57 and $184 \mathrm{hm}^{3}$. It is characterized as a shallow reservoir with a maximum water depth of $4.5 \mathrm{~m}$ and a mean of $2 \mathrm{~m}$. It is adversely affected by intensive agricultural [21] acting as a sink of fertilizers and agricultural effluents. The maximum allowable volume of the reservoir reaches $180 \mathrm{hm}^{3}$, of which only $60 \mathrm{hm}^{3}$ are available to cover irrigation needs as the water level of the reservoir has to be higher than $+46.40 \mathrm{~m}$.

The objective of the present paper is to address water related ES through SWAT model in such a Mediterranean reservoir. Our goal is to simulate over a long period of time under different climate and management scenarios (a) water availability, (b) sediment regulation and (c) water quality in terms of nutrient loading and to depict their effect to water-related ES. We also aim at the preparedness of planning adaptive management strategies not only in Greek basins but also in the wider Mediterranean area.

\section{Materials and Methods}

\subsection{SWAT Parametrization}

In this study, the river network and the sub-basins were manually delineated as Geographic Information Systems (GIS) shapefiles using maps from previous studies as guides. The watershed and stream network were based on the newly constructed drainage system of Lake Karla area with respect to the canals and ditches constructed in the basin. A total of 6 sub-basins were created. To estimate the spatial resolution of the slope in the sub-basins, a 100-m Digital Elevation Model (DEM) was used. Land use and soil type data were imported by the recent Corine Land Cover maps (2012). Meteorological data on precipitation, minimum and maximum temperature were compiled from the National Hellenic Meteorological Service (HNMS) from 1974 until 2004 for Larisa station. Additional precipitation data were obtained by four more stations in the watershed starting from 1979 until 2011. Modeling period started from 2012 until 2100. A total of 22 Hydrological response units (HRUs) were defined in the watershed using 15\%-15\%-30\% threshold values for land use, soil and slope overlay. The Penman-Monteith method was used for estimating potential evapotranspiration and surface runoff was calculated using the U.S. Soil Conservation Service curve number procedure.

\subsection{Scenarios}

The Climate change scenario adopted in this study was based on data from the Canadian Centre for Climate Modelling and Analysis and especially from third version of the Coupled Global Climate Model. The A1 storyline group describes a world of very rapid economic growth with new efficient technologies and low population growth. From this group, A1B scenario was selected as the more 
mediocre one until 2100 with resulting radiative forcing. These data were related to the data from climate stations located in the case study area in order to create precipitation and temperature time series for the 2012-2100 modeling period.

Therefore, five management scenarios were simulated. Scenario A is the more "natural" one with reservoir operation without irrigation and water transfer from Pinios is described. Scenario B includes the addition of irrigation abstractions (business as usual), and $\mathrm{C}$ adds water transfer from Pinios River. Scenario D raises irrigation abstractions by $20 \%$ and the last (E) models a land use change into a more water demanding crop in the area irrigated by the lake. These scenarios were further investigated to analyze the effects on the lake's water quantity and also quality by further calculating Nitrogen inflows and sediment transport, in relation with the affected ES.

\subsection{Relation with Ecosystem Services}

ES are classified reflecting the satisfaction of human needs as provision, regulation, culture and support. Water supply per se is defined as a provision ES and includes extractive and non-extractive uses while water quality can be defined as a regulation ES [22]. Not having established the minimum provision for users and/or optimal quality depending on uses, a conceptual connection is attempted without calculating any ES indices; that is why the grouping of Millennium Ecosystem Assessment of 2005 [23] is selected instead of the more detailed Common International Classification of Ecosystem Services (CICES) [24]. Water quantity was perceived as the remaining water volume after covering all needs of every scenario, plus the outflow since it reflects the residence time. For water quality, the deviation from point zero of the modeling is assessed as the concentration of nutrients. The scenarios are assessed by grading their possible effects at the end of the modeling period (2100), on water related ES in a simple scale as impaired, not affected or enhanced $(-, 0,+)$ based on the scenarios effects on land cover, water use, water quality, ES relevant literature and expert opinion.

\section{Results}

\subsection{Effects on Water Availability}

Karla's reservoir gains water from the rainfall, the watershed's surface runoff and the water diverted from Pinios and loses through evaporation, seepage, outflow and irrigation abstractions in a rate depending on each scenario, as presented in Figure 1. Scenario A provided a valuable insight for the "natural" function of the lake. The watershed surface runoff contribution is approximately 65 $\mathrm{Mm}^{3}$ whereas rainfall contributes $15 \mathrm{Mm}^{3}$. For the wettest year of the simulation, surface runoff increased more than 3.5 times reaching $240 \mathrm{Mm}^{3}$ and rainfall $25 \mathrm{Mm}^{3}$, whereas during the driest simulation year, surface runoff was reduced to $12 \mathrm{Mm}^{3}$ and rainfall to $9.5 \mathrm{Mm}^{3}$. During the warmest and dryer years, evaporation increased to $42 \mathrm{Mm}^{3}$ and outflow decreased to $12 \mathrm{Mm}^{3}$. Wetter years increased the lake's outflow to $24 \mathrm{Mm}^{3}$ and decreased evaporation to $28 \mathrm{Mm}^{3}$.

In scenario $\mathrm{B}$, the addition of irrigation abstraction and the hydrological balance recalculation without water transfer from Pinios revealed that the reservoir is unable to cover the agricultural needs $\left(35 \mathrm{Mm}^{3}\right)$ but only $20 \mathrm{Mm}^{3}$ on annual average. The rest hydrological components of the reservoir remain unaltered, except from the reservoir's outflow, which is reduced to 4 from $24 \mathrm{Mm}^{3}$ compared to the first scenario, due to irrigation abstractions, while many years had no outflow.

The third scenario includes the provision of Pinios River floodwater during the winter. On average, $30 \mathrm{Mm}^{3}$ of water are transferred into Karla Lake every year based on simulations to cover $35 \mathrm{Mm}^{3}$ of agricultural needs allowing an outflow of $19 \mathrm{Mm}^{3}$. The supply reaches up to $100 \mathrm{Mm}^{3}$ at wet years. Similarly, the fourth scenario increases by $20 \%$ the water abstractions for irrigation (from 35 to $40 \mathrm{Mm}^{3}$ ). Water transfer from Pinios was artificially increased on average to $34 \mathrm{Mm}^{3}$ (instead of $30 \mathrm{Mm}^{3}$ ) to cope with the augmented needs and reservoir and outflow reduced to $17 \mathrm{Mm}^{3}$ compared to $19 \mathrm{Mm}^{3}$ of the previous scenario. Scenario $\mathrm{E}$ is radically different from the previous ones as here the replacement of all agricultural crops with greenhouse farming required year around irrigation. Irrigation water demand is $80 \mathrm{Mm}^{3}$. Like the fourth scenario, water transfer from Pinios was artificial augmented at $64 \mathrm{Mm}^{3}$ on average and the outflow was formed at $8 \mathrm{Mm}^{3}$. In Scenarios C, D and E, 
despite the augmentation in water transfer, many years have deficient reservoir water budget affecting residence time.

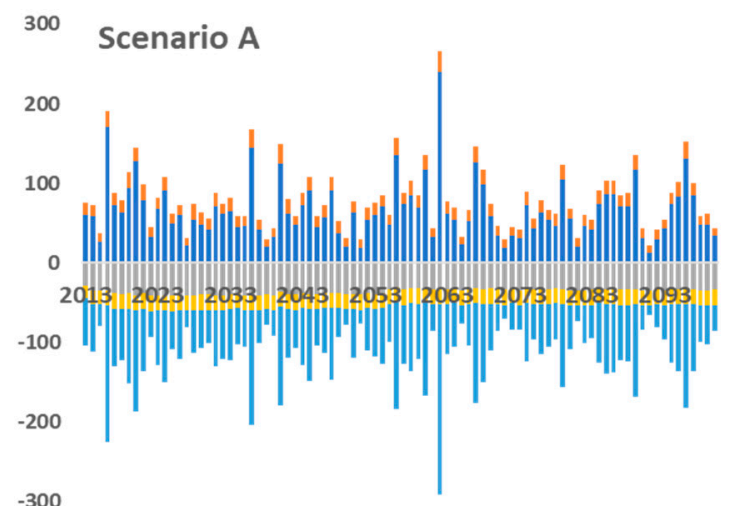

$-300$

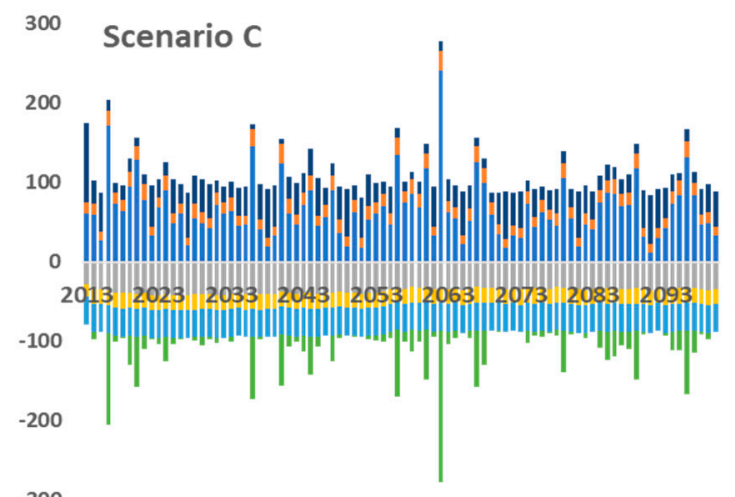

$-300$

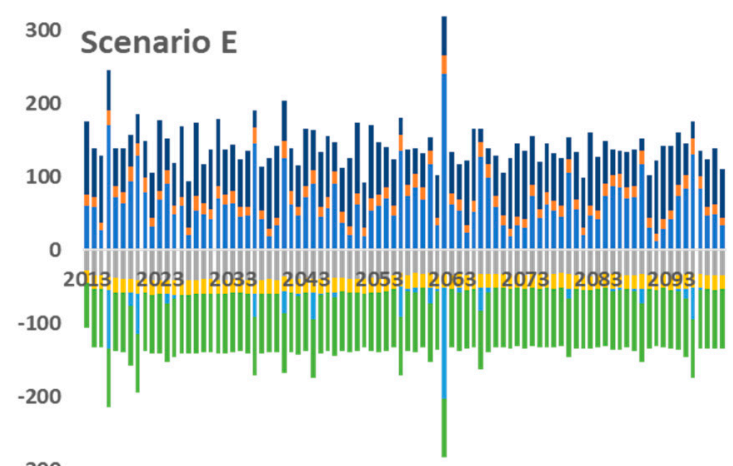

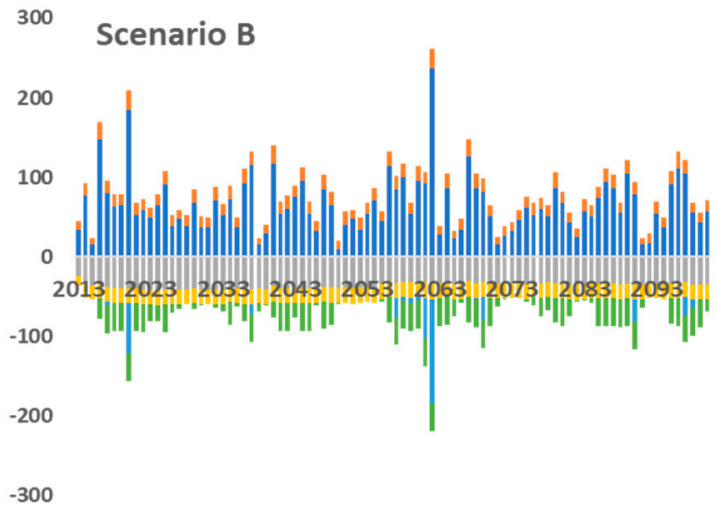

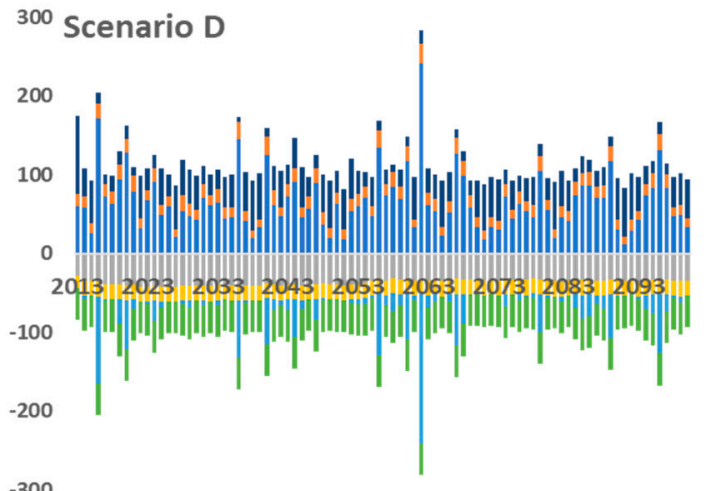

$-300$

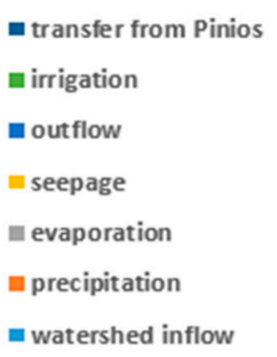

a watershed inflow

Figure 1. Annual hydrological budget of Lake Karla for 2012-2100 modeling period. X axis represents the years of the calibration and $\mathrm{Y}$ axis represents water volumes expressed in $\mathrm{Mm}^{3}$.

\subsection{Effects on Sediment Transfer}

The sediment transfer into the lake is the same for the first and second scenario since surface runoff remains unchanged and no transfer from Pinios takes place. The average amount of sediment that ends into the reservoir solely due to surface runoff is approximately 160,000 tons annually in all scenarios. Besides scenarios A and B, water transfer from Pinios River adds on average another 65,000 to 110,000 tons of sediment annually depending on the transferred volume of the scenarios C, D and E. Sediment transfer due to water transfer is extremely fluctuational, contributing from a minimum of 11,000 tons on a dry year with full reservoir capacity, to a maximum of almost 580,000 tons (Figure 2). $\mathrm{C}$ and D scenarios add important amounts of sediment, namely 5.84 million tons, enhancing by $40 \%$ the natural sedimentation process. In the more extreme scenario $\mathrm{E}$, these amounts are augmented by approximately $45 \%$ with an annual average of 266 tons. 


\subsection{Effects on Water Quality}

Water quality is approached as Nitrogen loading and especially in-lake nitrates concentrations, affected indirectly by irrigation abstractions and water transfer from Pinios River. Intra-annual fluctuations characterize the nitrogen concentrations independently of the scenarios (Figure 3). This is a result of the annual behavior of the hydrological components of the reservoir and the land uses. Higher concentrations are recorded in the first two cases and especially in scenario B were agricultural production is active without water abstraction from Pinios River.
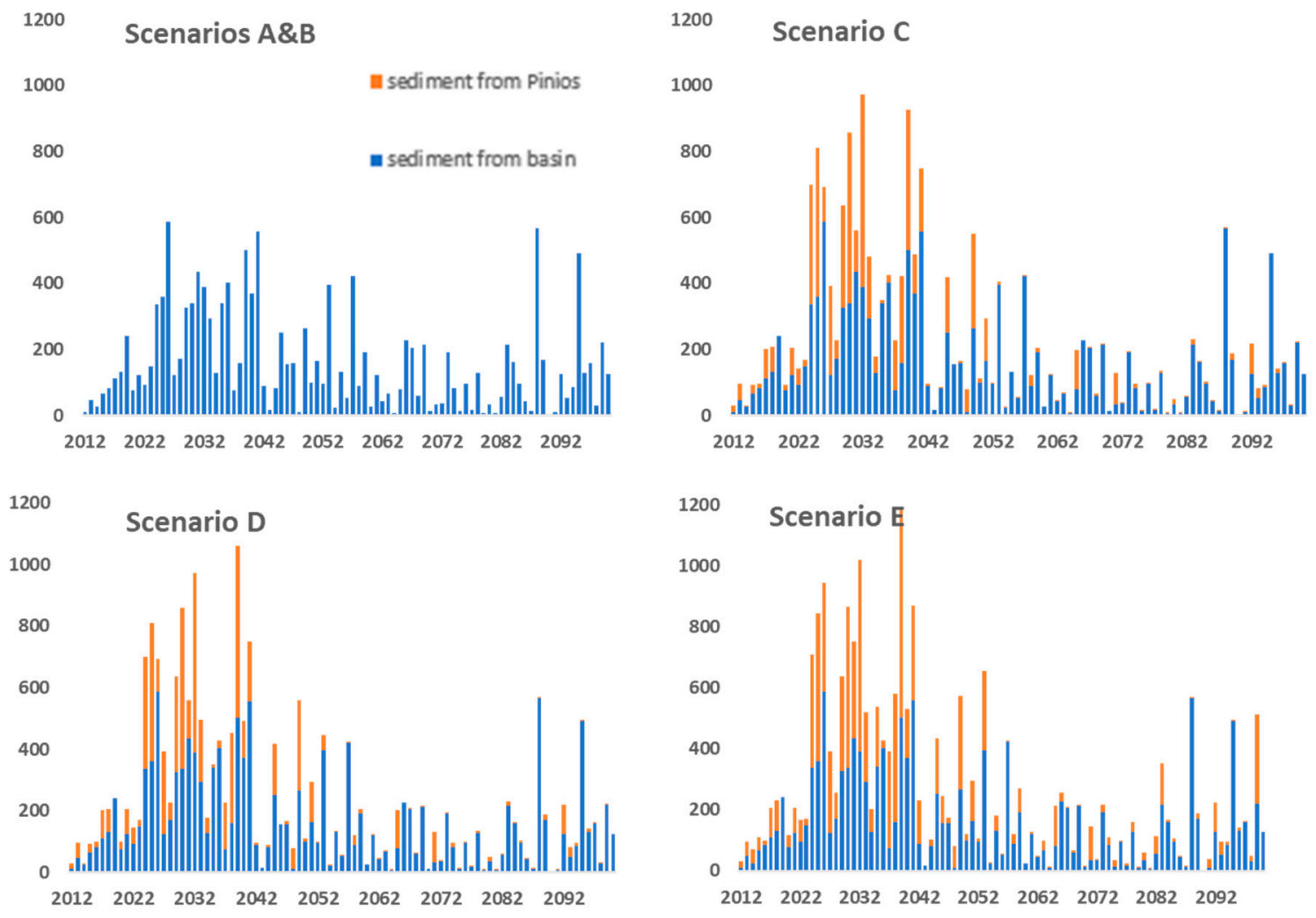

Figure 2. Annual sediment transfer in Lake Karla for 2012-2100 modeling period. All masses are expressed in thouand tons.

The water transfer acts in favor of a dilution effect when assessed annually. Looking at the modelled concentrations monthly, higher values are generated for a period from February until May with individual values exceeding $30 \mathrm{mg} \mathrm{L}^{-1}$ in all scenarios. The average nitrate concentration ranges from $2.30 \mathrm{mg} \mathrm{L}^{-1}$ for scenario $\mathrm{E}$ up to $3.19 \mathrm{mg} \mathrm{L}^{-1}$ for scenario B depicting a nitrogen-polluted system.

\subsection{Effects on Ecosystem Services}

The re-establishment of a new reservoir has targeted the increase of the provisioning services as well as the promotion of regulating services and yet, the re-enhancement of the cultural services delivered in the entire catchment area. The ES were assessed by taking into account the water quantity as the availability for covering irrigation needs, the sediment transfer as a negative effect on water turbidity, lake depth and nutrients concentration, the intensity of land uses and the water quality expressed in nitrogen concentration (Table 1). In some cases, the intensiveness of agricultural production (land uses) affected more our expert opinion based on the naturalness alteration and the stress on biodiversity despite the modelled results. 


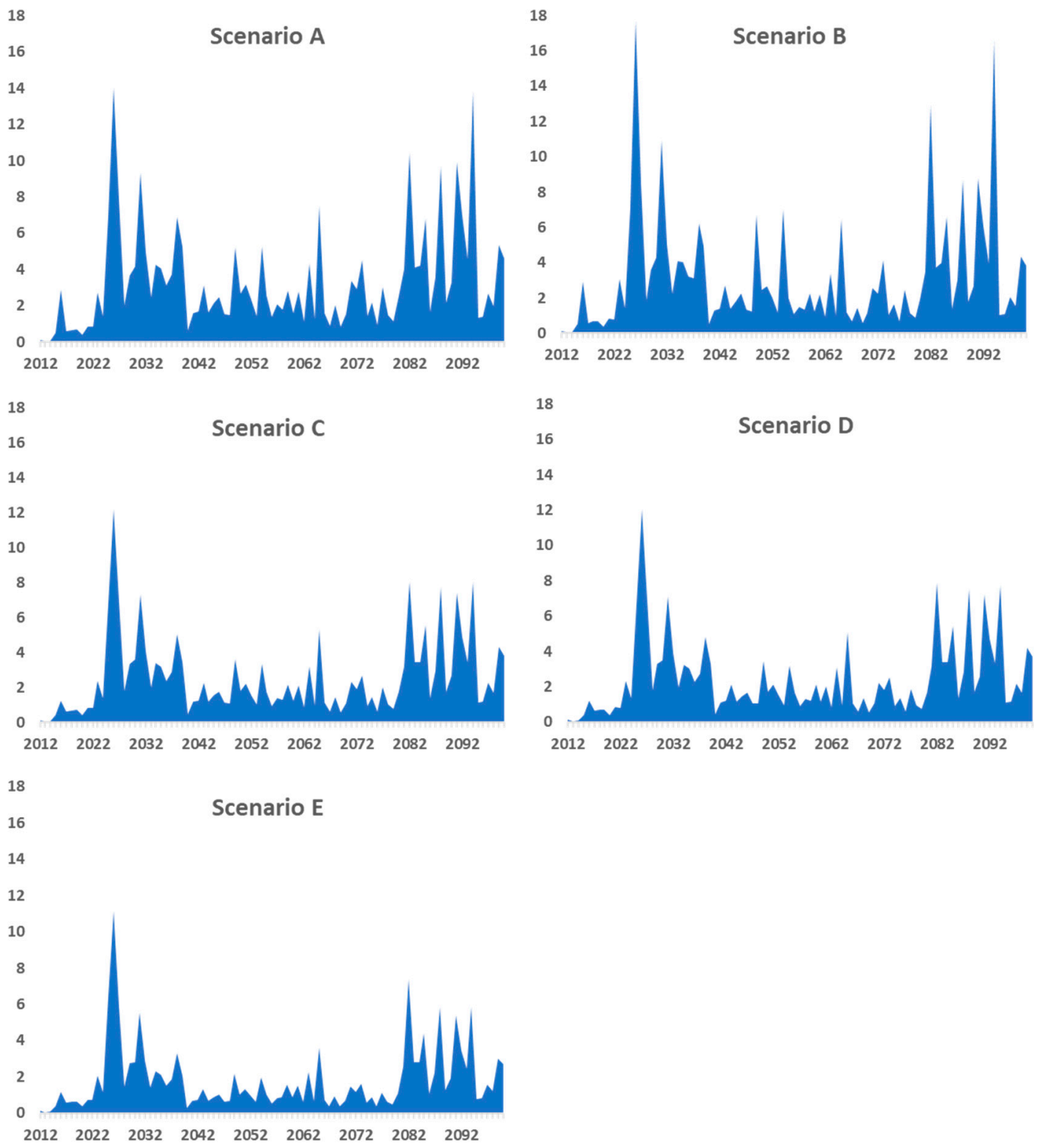

Figure 3. Variation of Nitrate concentration in Lake Karla for 2012-2100 modeling period. Concentrations are expressed in $\mathrm{mg} \mathrm{L}^{-1}$.

Table 1. Water related ecosystem services assessment for the five scenarios. - stands for impaired, 0 for not affected and + enhanced.

\begin{tabular}{ccccccc}
\hline ES Groups & ES & Sc. A & Sc. B & Sc. C & Sc. D & Sc. E \\
\hline \multirow{4}{*}{ Provisioning } & Food and fiber & - & - & 0 & + & + \\
& Genetic resources & + & 0 & - & - & - \\
& Fresh water (all uses) & - & - & + & + & + \\
\hline \multirow{3}{*}{ Regulation } & Erosion control & + & 0 & - & - & - \\
& Water purification & 0 & - & + & + & + \\
& Storm/ Flood protection & + & 0 & 0 & - & - \\
\hline \multirow{2}{*}{ Cultural } & Aesthetic values/Inspiration & + & 0 & 0 & - & - \\
& Recreation and Ecotourism & 0 & - & + & - & - \\
\hline \multirow{3}{*}{ Supporting } & Nutrient cycling & 0 & - & + & + & + \\
& Water cycling & - & - & + & + & + \\
& Habitats & + & - & 0 & - & - \\
\hline
\end{tabular}


Scenario 1 depicted a "natural" model. Scenario 2 affected negatively both water quality and quantity. Scenario 3 generated better results in terms of water volume and quality due to the water transfer from Pinios but more sediment transfer. Scenario 4's results were similar with the third one's, but slightly worse due to the more demanding agricultural production. The fifth scenario, despite being more demanding in terms of water use, resulted in high water quality and quantity but the worst in terms of sediment and land use pressures.

\section{Discussion-Conclusions}

Hydrological and biogeochemical catchment models are appropriate tools for dealing with water-related ES [11,25]. A modified SWAT model was used to simulate the hydrological status of Lake Karla and its watershed under a mild global warming projection. Five different reservoir and irrigation management scenarios were simulated to address how water transfer from Pinios River and agricultural abstractions would affect the lake's qualitive and quantitative characteristics.

It was acknowledging that agricultural systems can generate ES and in cases can even assist water quality by reducing nutrients and regulating climate [26], in the same time impact other ES. It has been documented that in Southern Europe, agriculture is the major water-using sector with a total freshwater share of $80 \%$ [27]. Climate change is another driver that affects the overall hydrological status of the watershed and, consequently, the lake inflows and outflows. The results clarified that water budget is sensitive and largely dependent by the water transfer from Pinios river. A maximum amount of $100 \mathrm{Mm}^{3}$ of water is allowed to be transferred from the river annually and such was the upper limit adopted in this survey. The water budget is aggravated under the prism of the "moderate" climate change scenario, affecting negatively the water residence time and in turn the system's self-purifying capacity. The ecosystem functioning is highly controlled by the hydrological flows since water availability governs their productivity [22]. As for the sediment transfer, the lake's trapping capacity is closely related to the absorbance of a variety of pollutants that will eventually be buried in sediments.

Nutrient modeling revealed high concentrations in all scenarios highlighting both the status of the lake due to water uses and the importance of the dilution effect. Although nutrient loading is, generally, expected to decline in warm Mediterranean areas due to the lower runoff and precipitation, higher concentrations are currently observed due to increased evapotranspiration [8]. Concerning our study area, the whole catchment is enlisted in the Nitrate Vulnerable Zones of Europe. The proper water management in such an agricultural area is needed to solve the tradeoff between the production increase and the system's loss of ability to support ecosystem benefits [26].

To conclude, given the nature and the purposes of the re-created Lake Karla, the optimal solution would be a scenario like the third, where human uses would not impair ecosystem naturalness and resilience and most water related ES would be enhanced. Our approach emphasizes the need to implement measures in the new reservoir, which should be embedded in the next cycle of River Basin Management Plans as the corner stone of the WFD implementation.

Author Contributions: Conceptualization, I.K. and D.L.; methodology, I.K. and A.D.; software, A.D.; formal analysis, A.D. and D.L.; resources, I.K.; data curation, A.D., I.K.; writing-original draft preparation, A.D. and D.L.; writing-review and editing, D.L.; supervision, I.K. All authors have read and agree to the published version of the manuscript.

Funding: This research received no external funding

Acknowledgments: The authors would like to thank the Management Body of the Eco-development Area of Karla-Mavrovouni-Kefalovrisi-Velestino-Pinios Delta and its staff for their support during the data gathering.

Conflicts of Interest: The authors declare no conflict of interest. 


\section{References}

1. Kandziora, M.; Burkhard, B.; Müller, F. Interactions of ecosystem properties, ecosystem integrity and ecosystem service indicators-A theoretical matrix exercise. Ecol. Indic. 2013, 28, 54-78, doi:10.1016/j.ecolind.2012.09.006.

2. Lu, Y.; Wang, R.; Zhang, Y.; Su, H.; Wang, P.; Jenkins, A.; Ferrier, R.C.; Bailey, M.; Squire, G. Ecosystem health towards sustainability. EHS 2015, 1, 1-5, doi:10.1890/EHS14-0013.1.

3. Burkhard, B.; Maes, J. Mapping Ecosystem Services, 1st ed.; Advanced Books: Sofia, Bulgaria, 2017; doi:10.3897/ab.e12837.

4. Bouwma. I.; Schleyer, C.; Primmer, E.; Winkler, K.J.; Berry, P.; Young, J.; Carmen, E.; Špulerová, J.; Bezák, P.; Preda, E.; et al. Adoption of the ecosystem services concept in EU policies. Ecosyst. Serv. 2018, 29, $213-$ 222, doi:10.1016/j.ecoser.2017.02.014.

5. Wood, S.L.; Jones, S.K.; Johnson, J.A.; Brauman, K.A.; Chaplin-Kramer, R.; Fremier, A.; Girvetz, E.; Gordon, L.J.; Kappel, C.V.; Mandle, L.; et al. Distilling the role of ecosystem services in the Sustainable Development Goals. Ecosyst. Serv. 2018, 29, 70-82, doi:10.1016/j.ecoser.2017.10.010.

6. Nelson, E.; Mendoza, G.; Regetz, J. Modeling multiple ecosystem services, biodiversity conservation, commodity production, and tradeoffs at landscape scales. Front. Ecol. Environ. 2009, 7, 4-11, doi:10.1890/080023.

7. Jeppesen, E.; Søndergaard, M.; Liu, Z. Lake restoration and management in a climate change perspective: An introduction. Water 2017, 9, 122, doi:10.3390/w9020122.

8. Geijzendorffer, I.; Chazée, L.; Gaget, E. Mediterranean Wetlands Outlook 2: Solutions for Sustainable Mediterranean Wetlands; Tour du Valat: Arles, France, 2018.

9. Kovats, R.S.; Valentini, R.; Bouwer, L.M.; Georgopoulou, E.; Jacob, D.; Martin, M.; Rounsevell, M.; Soussana, J.F. Europe. In Climate Change 2014: Impacts, Adaptation, and Vulnerability. Part B: Regional Aspects; Contribution of Working Group II to the Fifth Assessment Report of the Intergovernmental Panel on Climate Change; Cambridge University Press: Cambridge, UK; New York, NY, USA, 2014; pp. 1267-1326.

10. Loizidou, M.; Giannakopoulos, C.; Bindi, M.; Moustakas, K. Climate change impacts and adaptation options in the Mediterranean basin. Reg. Environ. Chang. 2016, 16, 1859-1861, doi:10.1007/s10113-016-1037-9.

11. Vigerstol, K.L.; Aukema, J.E. A comparison of tools for modeling freshwater ecosystem services. J. Environ. Manag. 2011, 92, 2403-2409, doi:10.1016/j.jenvman.2011.06.040.

12. Psomas, A.; Panagopoulos, Y.; Konsta, D.; Mimikou, M. Designing water efficiency measures in a catchment in Greece using WEAP and SWAT models. Procedia Eng. 2016, 162, 269-276, doi:10.1016/j.proeng.2016.11.058.

13. Pisinaras, V.; Petalas, C.; Gikas, G.D.; Gemitzi, A.; Tsihrintzis, V.A. Hydrological and water quality modeling in a medium-sized basin using the Soil and Water Assessment Tool (SWAT). Desalination 2010, 250, 274-286, doi:10.1016/j.desal.2009.09.044.

14. Stefanidis, K.; Panagopoulos, Y.; Mimikou, M. Impact assessment of agricultural driven stressors on benthic macroinvertebrates using simulated data. Science 2016, 540, 32-42, doi:10.1016/j.scitotenv.2015.08.015.

15. Bärlund, I.; Kirkkala, T.; Malve, O.; Kämäri, J. Assessing SWAT model performance in the evaluation of management actions for the implementation of the Water Framework Directive in a Finnish catchment. Environ. Modell Soft 2007, 22, 719-724, doi:10.1016/j.envsoft.2005.12.030.

16. Bekele, E.G.; Lant, C.L.; Soman, S.; Misgna, G. The evolution and empirical estimation of ecologicaleconomic production possibilities frontiers. Ecol. Econom. 2013, 90, 1-9, doi:10.1016/j.ecolecon.2013.02.012.

17. Radcliffe, D.E.; Reid, D.K.; Blombäck, K. Applicability of models to predict phosphorus losses in drained fields: A review. J. Environ. Qual. 2015, 44, 614-28, doi:10.2134/jeq2014.05.0220.

18. Bobori, D.C.; Ntislidou, C.; Petriki, O.; Chronis, I.; Kagalou, I.; Lazaridou, M. Macroinvertebrate and fish communities in the watershed of a re-constructed Mediterranean water body: Link to the ecological potential. Environ. Monit. Assess. 2018, 190, 106, doi:10.1007/s10661-018-6484-y.

19. Gkelis, S.; Panou, M.; Chronis, I.; Zervou, S.-K.; Christophoridis, C.; Manolidi, K.; Ntislidou, C.; Triantis, T.M.; Kaloudis, T.; Hiskia, A.; et al. Monitoring a newly re-born patient: Water quality and cyanotoxin occurrence in a reconstructed shallow Mediterranean lake. AIOL 2017, 8, 33-51, doi:10.4081/aiol.2017.6350.

20. Loukas, A.; Sidiropoulos, P.; Mylopoulos, N.; Vasiliades, L.; Zagoriti, K. Assessment of the effect of climate variability and change and human intervention in the lake Karla aquifer. Eur. Water 2015, 49, 19-31. 
21. Latinopoulos, D.; Mylopoulos, N.; Fafoutis, C. Using a market-type allocation system to confront water scarcity: An inter-district approach in Greece. Glob. Nest J. 2014, 16, 653-666.

22. Jujnovsky, J.; Almeida-Leñero, L.; Bojorge-García, M.; Monges, Y.L.; Cantoral-Uriza, E.; Mazari-Hiriart, M. Hydrologic ecosystem services: Water quality and quantity in the Magdalena River, Mexico City. Hidrobiológica 2010, 20, 113-126.

23. Millennium Ecosystem Assessment. Ecosystems and Human Well-Being: Synthesis; Island Press: Washington, DC, USA, 2005; p. 155.

24. Haines-Young, R.; Potschin M.B. Common International Classification of Ecosystem Services (CICES) V5.1 and Guidance on the Application of the Revised Structure. 2018. Available online: www.cices.eu (accessed on 16 May 2019).

25. Guswa, A.J.; Brauman, K.A.; Brown, C.; Hamel, P.; Keeler, B.L.; Sayre, S.S. Ecosystem services: Challenges and opportunities for hydrologic modeling to support decision making. Water Resour. Res. 2014, 50, 45354544, doi:10.1002/2014WR015497.

26. Gordon, L.J.; Finlayson, C.M.; Falkenmark, M. Managing water in agriculture for food production and other ecosystem services. Agric. Water Manag. 2010, 97, 512-519, doi:10.1016/j.agwat.2009.03.017.

27. European Commission. Water Framework Directive Intercalibration Technical Report. Part 2: Lakes. Ispra, Italy; European Commission: Brussels, Belgium, 2009.

(C) 2020 by the authors. Licensee MDPI, Basel, Switzerland. This article is an open access article distributed under the terms and conditions of the Creative Commons Attribution (CC BY) license (http://creativecommons.org/licenses/by/4.0/). 